\title{
Effects of caseinomacropeptide (CMP) on digestion regulation
}

\author{
M Yvon 1, S Beucher 1, P Guilloteau 2, \\ I Le Huerou-Luron 2, T Corring ${ }^{3}$
}

\author{
1 INRA, Laboratoire de Recherches Laitières, Domaine de Vilvert, 78352 Jouy-en-Josas Cedex; \\ 2 INRA, Laboratoire du Jeune Ruminant, 35042 Rennes Cedex; \\ 3 INRA Laboratoire d'Écologie et Physiologie du Système Digestif, \\ 78352 Jouy-en-Josas Cedex, France
}

\begin{abstract}
Summary - Caseinomacropeptide (CMP) is a 64-amino-acid-residue peptide which is released from $\kappa$-casein by gastric proteinases. This review sums up the knowledge concerning its effects on the digestive function. Part 1 recalls the origin and heterogeneity of CMP. Here we underline that there are various forms of CMP which differ by their glycosylation level and genetic mutation. Consequently the forms used for studying biological activities need to be defined accurately. Part 2 summarizes the effects of CMP on digestive secretions. The major effect is an inhibitory effect on acid gastric secretions. Simultaneously, the blood concentration of regulatory digestive peptides is modified. In part 3 we try to clarify the mechanisms of action of CMP. A slightly glycosylated form of CMP, the A variant, appears to be responsible for the biological activity. Evidence suggests that CMP triggers stimuli from intestinal receptors without being absorbed. The signal would be then transmitted to organs through regulatory digestive peptides.
\end{abstract}

glycomacropeptide / casein / digestive secretion / regulation / regulatory endogenous peptide

Résumé - Effet du caséinomacropeptide (CMP) sur la régulation de la digestion. Le caséinomacropeptide (CMP) est un peptide de 64 résidus d'acides aminés libéré de la caséine $\kappa$ par les protéases gastriques. Cette revue fait le point des connaissances sur ses activités de régulation de la fonction digestive. Dans une première partie nous rappelons l'origine et l'hétérogénéité du CMP, en soulignant qu'il existe plusieurs formes de CMP, qui se distinguent par leur niveau de glycosylation et par des mutations génétiques. Il est donc nécessaire de préciser les formes utilisées dans les études d'activités biologiques. La deuxième partie est une synthèse des activités du CMP sur les sécrétions digestives. Le principal effet est un effet inhibiteur sur les sécrétions acides gastriques. Parallèlement les taux sanguins des peptides régulateurs digestifs sont modifiés. Dans la troisième partie nous tentons d'élucider les mécanismes d'action du CMP. Une forme faiblement glycosylée du CMP variant $A$ serait responsable de l'activité biologique. Ce CMP déclencherait des stimuli à partir de récepteurs intestinaux, sans être absorbé. Le signal serait ensuite transmis aux organes par l'intermédiaire de peptides régulateurs digestifs.

glycomacropeptide / caséine / sécrétions acides gastriques / régulation / peptides régulateurs digestifs 


\section{INTRODUCTION}

Digestive functions are regulated by a number of nervous and hormonal mechanisms triggered by the sight, smell and intake of a meal. The different constituents of the diet and their degradation products also have various effects on the digestive tract, which are related to these nervous and hormonal mechanisms. Thus, dietary proteins and their degradation products are involved in the physiological regulation of digestion. Furthermore, other more specific regulatory mechanisms associated with particular peptides can be involved. Thus, milk proteins contain several peptide segments, which can be released during digestion and may have a particular biological activity (Maubois and Léonil, 1989). These peptides may act either directly as neurotransmitters or indirectly by stimulating secretions of regulatory endogenous peptides from intestinal receptors. Caseinomacropeptide (CMP), which is rapidly released during the gastric digestion of milk, might be one of these bioregulators. Several studies have shown its effects on digestive secretions and have tried to clarify its mechanism of action.

\section{ORIGIN, PHYSICOCHEMICAL CHARACTERIZATION AND PROCEDURES TO ISOLATE CMP}

\section{Origin and heterogeneity of CMP}

Cows' milk contains 2 groups of proteins, caseins, which are insoluble phosphopro-

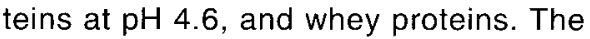
casein fraction represents $80 \%$ of the total nitrogen and is made up of 4 major proteins $\alpha \mathrm{S} 1, \alpha \mathrm{S} 2, \beta$ and $\kappa$ caseins, the proportions of which are $38,11,38$ and $13 \%$ respectively.
CMP in the first hydrolysis product resulting from the action of gastric proteinases (chymosin and/or pepsin) on $\kappa$-casein. The Phe $_{105}-\mathrm{Met}_{106}$ bond of $\kappa$-casein is the only one to be hydrolyzed during the first stage of milk clotting. CMP is the 106-169 fragment of $\kappa$-casein, its isoelectric $\mathrm{pH}$ ranges between 4 and 5 and it does not contain any aromatic amino acid. Moreover, its amino-acid composition and its sugar content make it very polar, and thus highly soluble in an aqueous medium contrary to the residual fragment 1-105 of $\kappa$-casein, which is named $\kappa$-paracasein.

CMP contains all the post-translational modifications of $\kappa$-casein (phosphorylation and glycosylation) and the mutations of the genetic variants. Thereby, like $\kappa$-casein, CMP is a very heterogeneous fraction. Seven forms of $\kappa$-casein can be distinguished by electrophoresis and 9 forms by ion-exchange chromatography. These forms correspond to different sugar and phosphorus contents. Five potential sites of glycosylation have been identified on bovine CMP (Zevaco and Ribadeau Dumas, 1984) (fig 1) and 5 different carbohydrate chains have been evidenced (Saito and Itoh, 1992) (fig 2). Tri- and tetrasaccharides containing at least 1 molecule of sialic acid represent around $93 \%$ of the carbohydrate chains bound to CMP. However k-casein glycosylation seems to occur at random and, consequently, different combinations are possible. On average, $40 \%$ of $\kappa$-casein is not at all glycosylated, $30 \%$ contains 1 or 2 sialic acids per mole, $18 \%$ contains 3 or 4 , and $5 \%$ contains more than 5 .

There are 2 major genetic variants of $\kappa$ casein which differ in 2 amino acids (Mercier et al, 1973). The $\mathrm{Thr}_{136}$ and $\mathrm{Asp}_{145}$ residues of the $A$ variant are replaced by Ile and Ala respectively in the B variant. These mutations make the $B$ variant more hydrophobic than the A variant. Moreover, the variants do not have the same level of glycosylation since, on the one hand, the 
$\mathrm{Thr}_{136}$ residue is a potential site of glycosylation and, on the other hand, the carbohydrate chains of the BB genotype contain more sialic acid than the other genotypes (Robitaille et al, 1991).
The CMP primary structure is relatively well preserved in the different species: sheeps, goats and buffalos share $71-84 \%$ of homology with bovine CMP; in humans and pigs, the percentage of homology

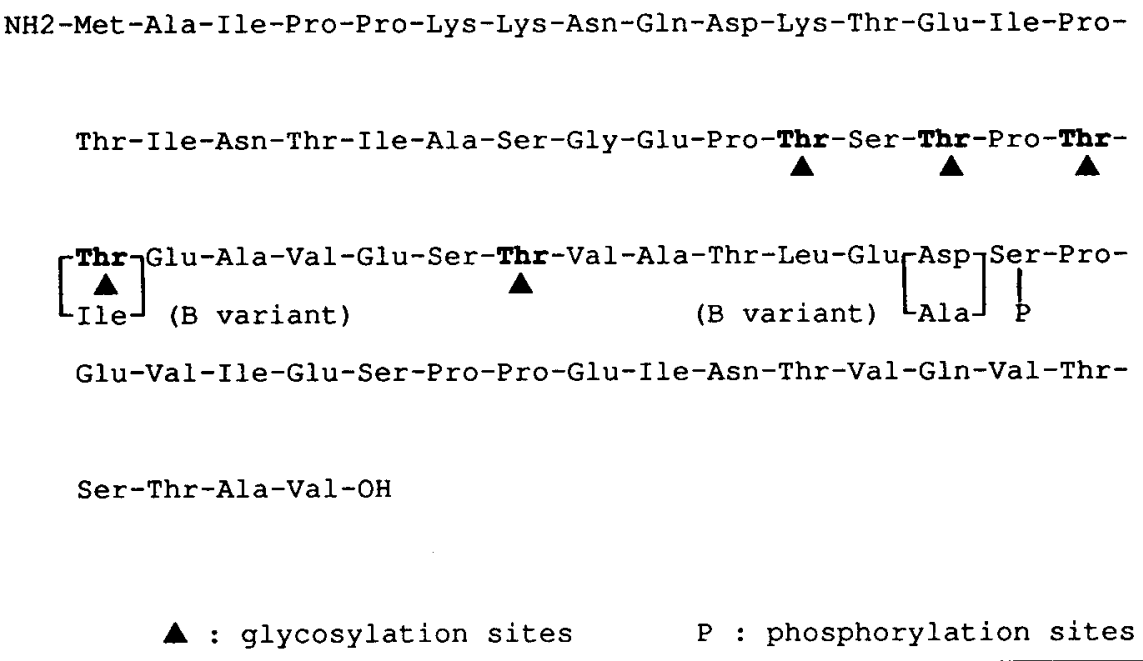

Fig 1. Primary structure of the $A$ and $B$ genetic variants of bovine caseinomacropeptide.

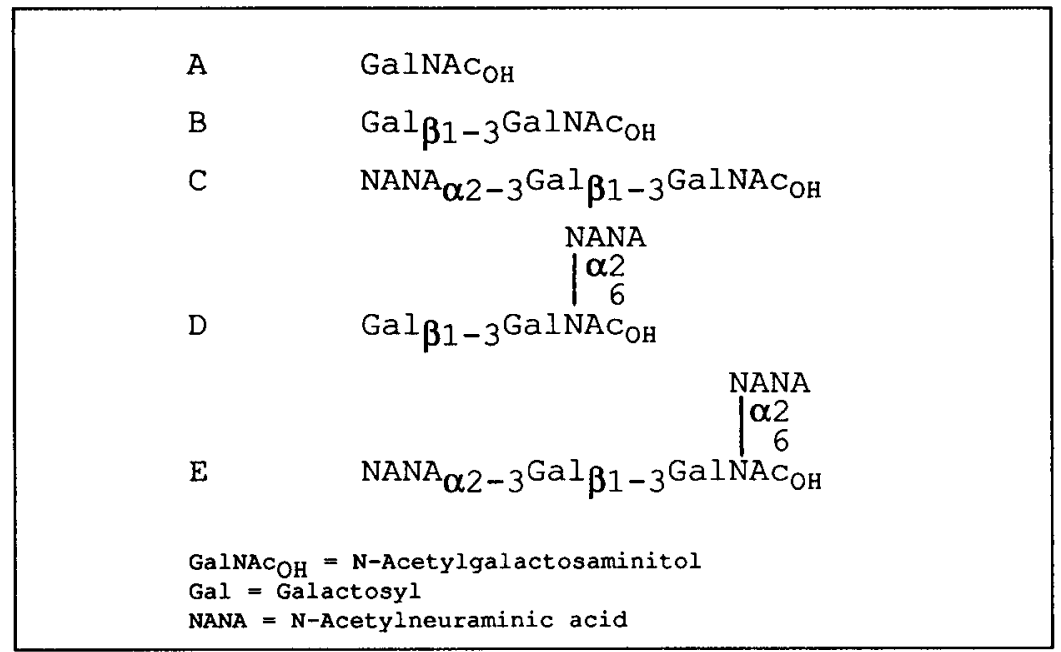

Fig 2. The complete chemical structure of the 5 carbohydrate units isolated from bovine normal $\mathrm{K}$ casein taken 3 months after parturition (Saito and Itoh, 1992). 
reaches 55\% (Mercier and Chobert, 1976). It should be noted that the 5 Thr residues that are binding sites for carbohydrate chains are well preserved and in particular the Thr residues located at positions 26 and 31 in bovine CMP, which are to be found in the 5 species mentioned above.

\section{Methods of preparation of CMP for studying biological activity}

CMP is generally prepared in the laboratory by controlled hydrolysis of free $\kappa$-casein by chymosin or pepsin. Residual protein and $\kappa$-paracasein are then eliminated by precipitation with trichloroacetic acid (TCA). Nevertheless, the heterogeneity of CMP causes differences in the solubility of its fractions in the presence of TCA. The glycosylated fractions remain soluble up to $12 \%$ TCA final concentration, whereas the non-glycosylated fraction precipitates from a concentration level of 4 or $5 \%$ and remains almost insoluble at $12 \%$ (Vreeman et al, 1986). As a result the $12 \%$ TCA soluble component is generally called glycomacropeptide (GMP). After elimination of TCA, this fraction (preparation 1) was used for several studies on biological activities in dogs and rats (Shlygin et al, 1971; Chernikov et al, 1974; Stan et al, 1974; Vasilevskaya et al, 1977; Chernikov et al, 1979). For some studies, a further fractionation was made on G-75 Sephadex (Stan et al, 1983) or G50 Sephadex (Aleinik et al, 1986). However, the fractions obtained and tested have never been characterized with accuracy as regards their glycosylation and phosphorylation levels or their genetic variants.

An industrial preparation (preparation 2) was used to study gastric secretions in the calf (Legeas, 1983; Guilloteau et al, 1986, 1994). The HPLC analysis of this product revealed that it contained the total CMP, ie the non-glycosylated and the glycosylated - fractions of the 2 main genetic variants of $\kappa$-casein (the $A$ and $B$ variants). Moreover, this product was slightly contaminated by the 1-23 fragment of $\alpha S 1$-casein.

Recently, in order to study pancreatic secretions in the pig, Beucher (1993) and Beucher et al (1994) have used the method developed by Savalle et al (1989), to prepare in vitro a hydrolysate similar to the digesta emptied from the calf abomasum during the $10 \mathrm{~min}$ following whole casein ingestion. The peptide fraction of the hydrolysate was separated from caseins by isoelectric precipitation ( $\mathrm{pH} 4.6$ ) of caseins, and then desalted by ultrafiltration. The total CMP represented about $70 \%$ of this peptide fraction, glycosylated CMP accounting for about half the total CMP. The A and $B$ variants were found in the proportion $2: 1$. The contaminants consisted of a fragment of $\alpha S 1$-casein (1-23) and of $\beta$-lactoglobulin representing 20 and $7 \%$ respectively. This non-purified fraction (preparation 3) was used to measure pancreatic secretion in the pig. Moreover, these authors have further fractionated this preparation 3 by reversephase HPLC in order to study the release of cholecystokinin (CCK) in an isolated rat duodenojejunum. The non-glycosylated CMP of both $A$ and $B$ variants $\left(C_{A}\right.$ and $\left.C M P_{B}\right)$, the slightly glycosylated fractions of the same variants $\left(\mathrm{GMP}_{2 \mathrm{~A}}\right.$ and $\left.\mathrm{GMP}_{2 \mathrm{~B}}\right)$, and $\mathrm{a}$ mixture of highly glycosylated fractions of both variants, called $\mathrm{GMP}_{2}$, were therefore isolated.

\section{EFFECTS OF CMP ON THE DIGESTIVE FUNCTION}

The role played by CMP on the digestive function has been studied by several teams since 1970 . The first hypotheses were put forward by scientists from the Nutrition Institute of the Moscow Academy of Medicine, who emphasized the role of this peptide on gastric secretions in the newborn mammal after intestinal absorption under its quasi- 
intact form. Since then, other teams have worked on this subject using different approaches.

In the following review, we have chosen to exclude observations made using whole casein or whole casein hydrolysates; the effects observed after intravenous injection of these products, especially vomiting and the inhibitory effects of the digestive myoelectrical activity (Vasilevskaya and Klimashima, 1979; Stan et al, 1983) seem to result from other peptides with an opiate activity (Stan et al, 1983, 1986; Stan and Ekimovsky, 1987).

\section{Studies on the intact animal}

\section{Intravenous or parenteral infusions of CMP preparations}

The intravenous or parenteral infusion of total GMP (preparation 1) inhibits the gastric acid secretion induced by different stimu- lants, such as the gastrin C-terminal tetrapeptide, pentagastrin, histamine, and the administration of meat or bread, in dogs fitted with a Pavlov or Heidenein pouch (Shlygin et al, 1971; Chernikov et al, 1974; Vasilevskaya et al, 1977). On the contrary, it stimulates the secretion of gastric proteinases in dogs with a Heidenein souch (Vasilevskaya et al, 1977). In these experiments, GMP were briefly infused and the quantities used varied considerably from one study to another (from 0.1 to $3.3 \mathrm{mg} / \mathrm{kg}$ LW). The response time was relatively long (1-2 $\mathrm{h}$ following infusion) (fig 3 ) and the effects lasted from 3-5 $\mathrm{h}$. The inhibitory effect on gastric acid secretion was reproduced in rats using an isolated fraction of GMP (Stan et al, 1983). This effect could be in good agreement with the decrease in gastrin levels in the blood and in the antral tissue observed by Aleinik et al (1986). In this case, however, the quantities used (33-55 mg/ kg LW) were higher than in dogs (particularly as it was a purified fraction) and the response time was only $30 \mathrm{~min}$. Other

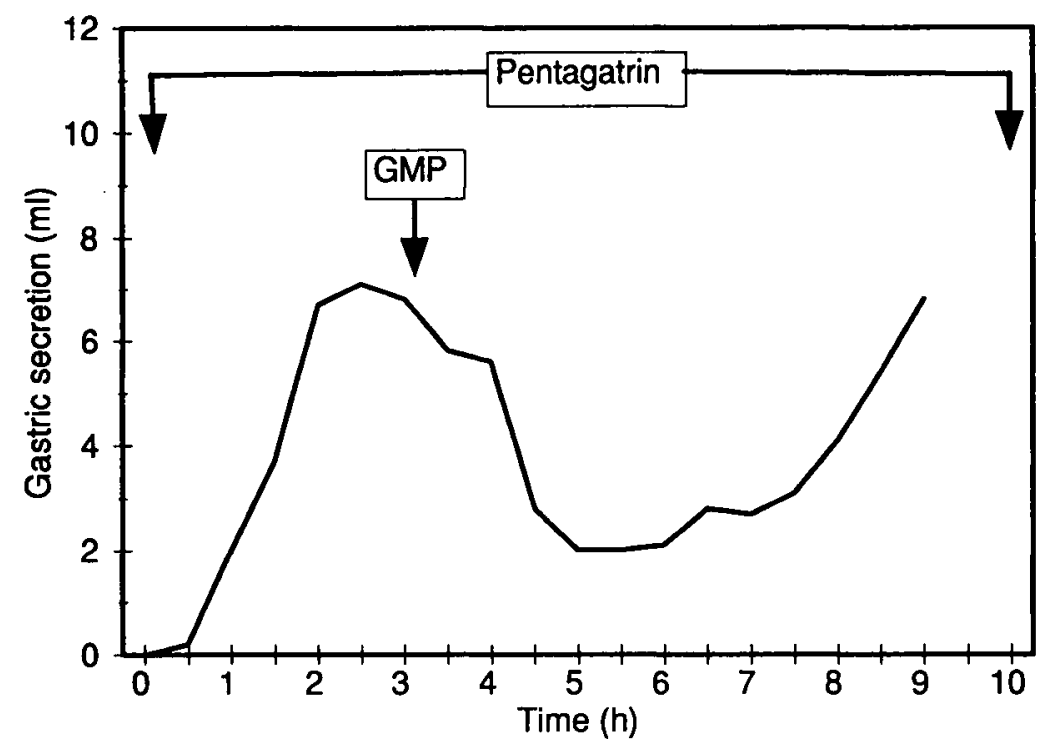

Fig 3. Effects of intravenous glycomacropeptide (GMP) infusion on gastric secretion stimulated by repeated infusion of pentagastrin (every $20 \mathrm{~min}$ ) in dog (data from Vasilevskaya et al, 1977). 
studies were made in preruminant calves fitted with a gastric pouch (developed by Guilloteau and Lecalve, 1977) and fed with a milk replacer based on CMP-free whey proteins. The intravenous infusion of CMP during the meal (preparation 2, at doses equal to $2 \mathrm{mg} / \mathrm{kg} \mathrm{LW}$ ) induced a slight decrease in the concentration of $\mathrm{H}^{+}$ions in the abomasal secretion, but it did not lead to significant variations in the quantities of gastric secretions produced (juice, acids and enzymes) compared to control animals receiving no infusion or an infusion of physiological salt solution (Legeas, 1983; Guilloteau et al, 1986, and unpublished results).

\section{Oral or enteral administration of CMP preparations}

Acute experiments conducted on humans have shown that oral administration of $4 \mathrm{~g}$ of CMP (preparation 2) decreased by $15 \%$ the cumulated acid secretion after $30 \mathrm{~min}$. This decrease was not due to the buffer effect of CMP, and such an effect was not observed at the level of $1 \mathrm{~g}$ (Bonfils and Roger, personal communication). When incorporated into calf food at the same level as in cows' milk (210 mg/kg LW), CMP (preparation 2) had an inhibitory effect on both gastric secretion (juice, acids and enzymes) and plasma concentrations of gastrin and especially CCK. These effects were observed during the first $2 \mathrm{~h}$ post prandial. By contrast somatostatin concentrations increased during the same period. Ingestion of CMP at a 5-fold higher level reduced or cancelled these effects (Legeas, 1983; Guilloteau et al, 1994, and unpublished results). In rats, jejunal perfusion of a fraction of CMP (at the level of $150 \mathrm{mg} / \mathrm{kg}$ LW) induced a decrease (by $38 \%$ ) in gastric secretions (juice and acid) stimulated by pentagastrin, 25 min after the beginning of the perfusion (Aleinik et al, 1986). Lastly, the duodenal perfusion of preparation 3 of $\mathrm{CMP}$ in the pig for $30 \mathrm{~min}$, at a level equal to that emptied from the stomach during the first 10 min following a meal containing $16 \%$ casein (around $10 \mathrm{mg} / \mathrm{kg} \mathrm{LW}$ ), increased the flow of pancreatic juice and proteins 45-60 min after the beginning of the perfusion (fig 4) (Beucher, 1993).

\section{Studies on isolated organs}

Aleinik et al (1986) used the isolated and nerveless stomach of a previously anaesthetized young rat. The organ was immersed in a Krebs solution, the serous membrane was thus irrigated. Pentagastrin was added to stimulate acid secretion. Addition of a fration of GMP at a level of $1 \mathrm{mg} / \mathrm{ml}$ in the immersion solution induced a $51 \%$ decrease in the stimulated acid secretion after $30 \mathrm{~min}$.

The effects of CMP on CCK release have been studied using a model of isolated and vascularized rat duodenojejunum developed by Cuber et al (1989). This model was used for eliminating the other stimuli liable to be involved in the in vivo secretion. The intraluminal infusion of preparation 3 for $30 \mathrm{~min}$, at a dose equal to that following a meal, immediately induced an increase in the CCK level in the blood, which reached a maximal value during the first $10 \mathrm{~min}$; this level persisted throughout the infusion (Beucher et al, 1994). The response to the different isolated fractions of this preparation showed that this effect was mainly due to the poorly glycosylated fraction of the $A$ variant.

\section{STUDY OF THE MECHANISM OF ACTION OF CMP}

It is difficult to review the results obtained by the different teams who have worked on 4 mammal species (rats, dogs, pigs and calves) using different approaches. The nature and doses of the products used vary considerably between the studies, and the 


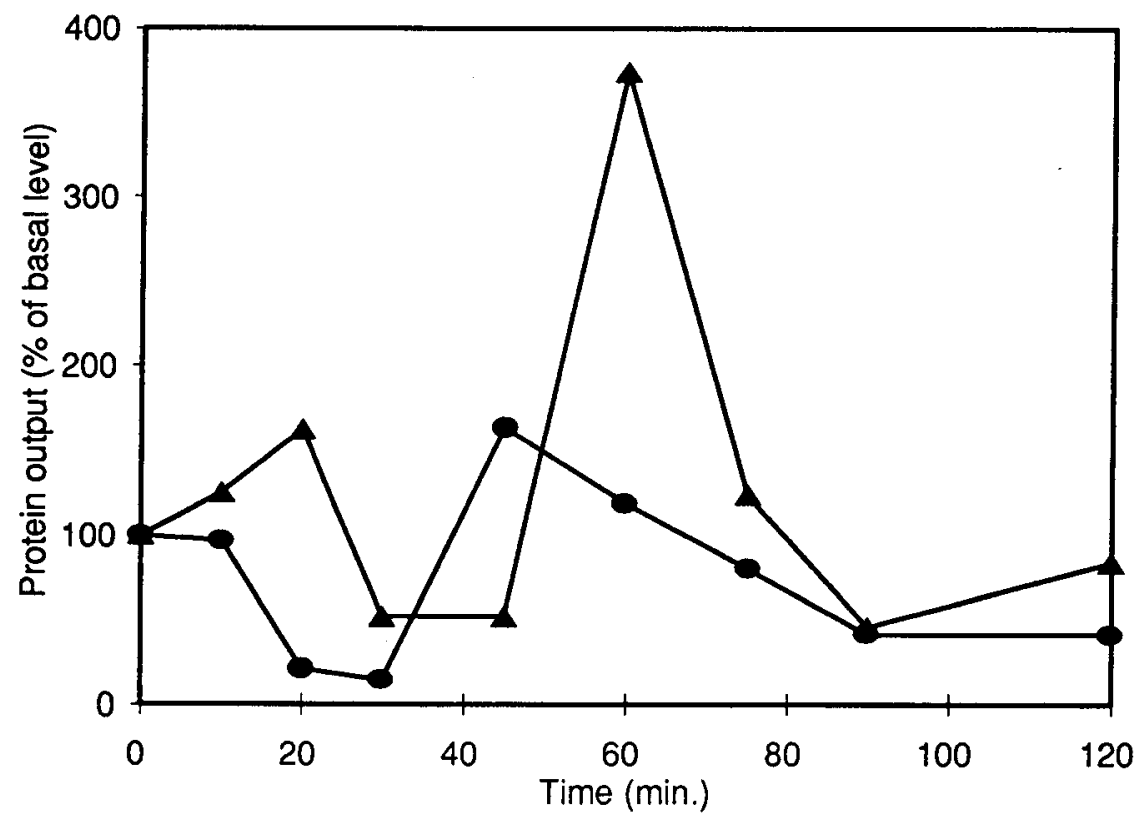

Fig 4. Effects of duodenal infusion of CMP preparation $3(\mathbf{A})$ and CMP-free casein ( $\mathbf{O})$ on the pancreatic protein output in pig expressed as percentage increase above the basal level (data from Beucher, 1993).

experimental protocols of the Russian research team often do not refer to any control treatment (infusion of physiological salt solution, etc). It is even more difficult to interpret and put forward hypotheses on the mechanisms involved since the measurements of the various digestive parameters and regulation factors have been performed in different species and using different protocols. However, from the results of these studies, it is possible to define the fractions of CMP responsible for the observed effects and to make assumptions concerning the mechanisms of regulation involved.

\section{Identification of the active forms of CMP}

The increase in pancreatic juice and proteins in the pig is not related to the protein mass of the fraction perfused into the intesti- nal lumen since administration of a 20-fold larger amount of CMP-free casein had no effect (Beucher, 1993). Moreover, the pancreatic secretion responses observed after duodenal infusion of different digesta are correlated to their CMP content (Beucher, 1993). In the calf the gastric secretion responses depend on the dietary proportion of CMP (Guilloteau et al, 1994) and the same applied to the man. CMP therefore appears to be responsible for the observed effects.

The nature of the CMP fraction seems to play a determining role. It can affect the response time. In the dog, for example, one fraction inhibits the acid secretion immediately after the intravenous infusion, whereas another fraction will have a response time ranging between 1.5 and $2 \mathrm{~h}$ (Stan et al, 1986). Two different fractions can have opposite effects on the acid secretion stim- 
ulated by pentagastrin (Stan et al, 1983). However, the content of these fractions has neither been identified nor precisely characterized. By applying different hydrolysis treatments to GMP before intravenous injection (fig 5), Chernikov et al (1979) demonstrated that the whole CMP molecule is not necessary for peptide activity but that carbohydrate chains are essential. This was confirmed by Beucher et al (1994) who demonstrated that luminal infusion of the non-glycosylated fraction of the peptide into an isolated rat duodenojejunum had no effect on the release of CCK, unlike certain glycosylated forms.

The number of bound carbohydrate chains, their nature and binding site seem to be involved in the biological activity of the molecule (Beucher et al, 1994). The fraction containing the slightly glycosylated forms of the A variant of CMP, when perfused alone in the rat duodenojejunum, highly stimulated the release of CCK. Most glycosylated forms were inactive. The $B$ variant of CMP (which differs from the $A$ variant only in 2 amino-acid residues) with a glycosylation level equivalent to the active fraction had no effect. Finally the presence of sialic acid at the extremity of the carbohydrate chains seems to be essential to CMP activity, since the removal of this residue eliminated the activity. However, the results obtained by Chernikov et al (1979) suggest that GMP desialylation does not modify its inhibitory effect on gastric secretions in the dog, but elimination of sialic acid residues (by controlled heat treatment) was not verified in this study. Thus, we can conclude that a minor form $(<20 \%)$ of CMP, processing on the Thr 21 a carbohydrate chain that ends with a sialic acid, is responsible for the observed biological activities. It should be noticed that this Thr residue, specificic of the A variant, is particularly well preserved in milk CMP from various species.

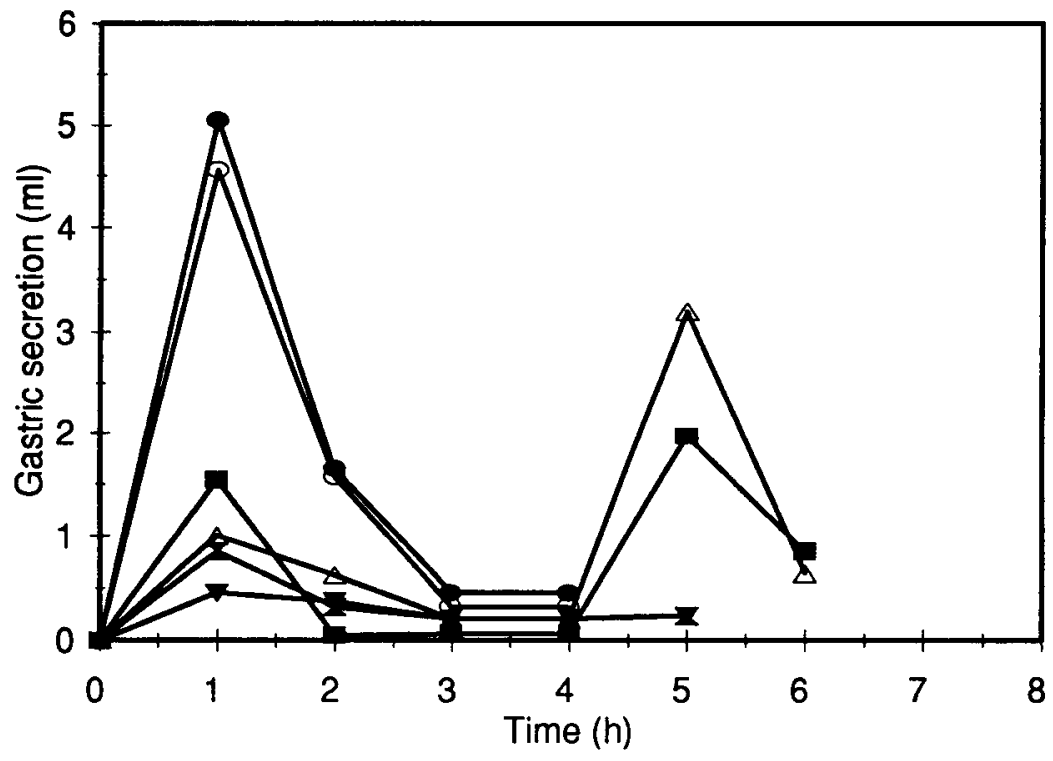

Fig 5. Effect of hydrolysis treatments of GMP on its ability to inhibit post-feeding gastric secretion in dog. CMP infusion made $1 \mathrm{~h}$ before the $100 \mathrm{~g}$ meat meal. Control $(\bullet)$ : without GMP infusion; $1(\mathrm{O})$ : GMP after carbohydrates hydrolysis $\left(2 \mathrm{~N} \mathrm{HCl}, 110^{\circ} \mathrm{C}, 4 \mathrm{~h}\right) ; 2(\square)$ : GMP without treatment; $3,4(\mathbf{X}, \Delta)$ : GMP hydrolysed by trypsin and pepsin, respectively; $5(\nabla)$ : desialylated GMP $\left(0.1 \mathrm{~N} \mathrm{HCl}, 80^{\circ} \mathrm{C}, 90 \mathrm{~min}\right.$ ) (data From Chernikov et al, 1979). 


\section{Mechanisms of action of GMP}

GMP thus seems to be responsible for the inhibitory effects of the stimulated acid secretions and for the increase in pancreatic secretions in vivo. Suppression of the vagal innervation or anaesthesia of the rat do not modify its inhibitory effect on gastric secretions in the rat. Aleinik et al (1986) have thus assumed that local cellular mechanisms might be involved. This hypothesis has been confirmed by showing that GMP can inhibit or stimulate secretions from isolated organs from rat (stomach and duodenojejunal loop) that are not, therefore, subjected to the influences of the central nervous system, or to the humoral system of the organism (Aleinik et al, 1986; Beucher et al, 1994).

Contrary to the hypotheses made by Chernikov et al (1979) and Aleinik et al (1986), it may not be necessary for the peptide or some active fragments to enter the blood to inhibit gastric secretion (Beucher et al, 1994). The rapidity of the response at the very beginning of the CMP infusion in the lumen of the rat intestinal loop suggests that the peptide absorption is probably unnecessary and that the stimulus is triggered on the mucous side of the intestinal cell. These hypotheses are supported by a much longer response time (30 $\mathrm{min})$ when the peptide is in contact with the serous membrane of an isolated stomach (Aleinik et al, 1986). Moreover, the doses responsible for the effect in the intestinal loop $(50 \mu \mathrm{g} / \mathrm{ml}$, mucous side) are about 10 times lower than used in the stomach $(400 \mu \mathrm{g} / \mathrm{ml}$, serous side). Finally, considering experiments with intravenous infusion of CMP, it is difficult to believe that the latter might act as plasma antigastrin under physiological conditions; the doses infused corresponded to plasma concentrations varying from 0.1 to $5 \mathrm{pmol} / \mathrm{ml}$ (and sometimes $65 \mathrm{pmol} / \mathrm{ml}$ ) whereas the gastrin concentrations usually range between 0.015 and $0.1 \mathrm{pmol} / \mathrm{ml}$. To confirm these results, it would be necessary to define a GMP assay in the blood plasma and to measure its content after milk ingestion by a young mammal.

Therefore, GMP probably acts by triggering stimuli from intestinal receptors. The release of CCK produced by the I cells may be induced by a cholinergic mechanism, but according to Cuber et al (1990), the luminal nutrients act directly on I cells. By fixing directly on the luminal receptors, the GMP could favour the release of CCK. In the same way, it could have a direct influence on other endocrine cells of the digestive tract like $D$ cells and $G$ cells, producing somatostatin and gastrin, respectively. Its inhibitory effect on acid secretion and the level of gastrin could be related to a high somatostatin production (Guilloteau et al, 1994).

Considering the diversity of both the models used and the experimental protocols (method, digestive tract level, doses, etc), it is very difficult to link all the phenomena observed during the different studies. However, the results indicate that this peptide, resulting from the food protein digestion, probably plays a part in regulating digestion under physiological conditions.

\section{CONCLUSION}

GMP, which was identifed in the gastric effluents of calves and newborn lambs immediately after milk or colostrum ingestion (Yvon and Pelissier, 1987; Yvon and Pelissier, 1993) thus appears to be a biologically active molecule. This raises the question of the biological significance of this peptide in a diet intended for young mammals, particularly as the primary structure of this peptide is relatively well preserved in the species. Given the importance of its inhibitory effects over the digestive function during the first hour following administration, its early release after meal ingestion in the gastrointestinal tract could attenuate the postfeeding stimulation of digestive 
secretions and, consequently, enable the colostrum proteins such as lactoferrin and immunoglobulins to escape hydrolysis and play a role in the development of the intestinal flora and in the immunity of the young (Reiter, 1978).

GMP (in the intact or fragment form) could trigger stimuli from intestinal receptors without being absorbed. This would require the presence of carbohydrate chains containing sialic acid. The signal induced may be transmitted to organs via the stimulation or inhibition of the production of regulatory digestive peptides. Further studies will be necessary to validate these hypotheses. They should, in particular, define the structural characteristics affecting the peptide activity and demonstrate the presence of receptors in the intestinal mucous membrane. They should also demonstrate that the peptide is not absorbed and confirm its effect on the production of different regulatory digestive peptides (somatostin, gastrin, secretin) by gastrointestinal cells using isolated organs or culture cells.

\section{ACKNOWLEDGMENTS}

We thank S Fillon, F Gousset, S Le Gall, V Natu and $A$ Bouroche for the translation into English.

\section{REFERENCES}

Aleinik SI, Stan EY, Chernikov MP (1986) Study of the mechanism of acid secretion inhibition with $\mathrm{k}$-casein peptides in the stomach. Fiziol Zh SSSR 72, 799803

Beucher S (1993) Effets de produits de digestion gastrique de caséine sur les sécrétions bilio-pancréatiques chez le porc et sur la libération de CCK par les cellules intestinales de rat. Thèse Université Paris VII, France

Beucher S, Levenez F, Yvon M, Corring T (1994) Effet du caseinomacropeptide sur la libération de cholecystokinine chez le rat. Reprod Nutr Dev 34, 613-614

Chernikov MP, Nikol'skaya GV, Stan EY, Shlygin GK, Vasilevskaya LS (1974) Biological significance of casein glycomacropeptide. Vopr Pitan 2, 21-25
Chernikov MP, Stan EY, Vasilevskaya LS, Shlygin GK (1979) Heterogeneity of $\mathrm{x}$-casein glycomacropeptide and the physiological activity of its fractions. Vopr Pitan 5, 22-26

Cuber JC, Vilas F, Charles N, Bernard C, Chayvialle JA (1989) Bombesin and nutrients stimulate release of CCK through distinct pathways in the rat. Am J Physiol 256, G989-G996

Cuber JC, Bernard G, Fuskiki T, Bernard C, Yamanishi R, Sugimoto E, Chayvialle JA (1990) Luminal CCKreleasing factors in the isolated vascularly perfused rat duodenojejunum. Am J Physiol 259, G191-G197

Guilloteau $\mathrm{P}$, Lecalve JL (1977) Technique de réalisation d'une poche abomasale chez le veau en vue de l'obtention de suc gastrique pur. Am Biol Anim Bioch Biophys 17, 1044-1060

Guilloteau P, Chayvialle JA, Mendy F et al (1986) Effet du caseinomacropeptide (CMP) sur la sécrétion gastrique et les taux circulants d'hormones digestives chez le veau préruminant. Reprod Nutr Dev 27, 287 288

Guilloteau P, Le Huërou-Luron I, Chayvialle JA et al (1994) Effet du caseinomacropeptide sur la sécrétion gastrique et les taux de peptides régulateurs circulants chez le veau préruminant. Reprod Nutr Dev $34,612-613$

Legeas M (1983) Effets de certains peptides issus de I'nydrolyse des caséines sur la régulation de la digestion chez le veau préruminant. Thèse université de Rennes, France

Maubois JL, Léonil J (1989) Peptides du lait à activité biologique. Le lait 69, 245-269

Mercier JC, Chobert JM (1976) Comparative study of the amino-acid sequences of the caseinomacropeptides from seven species. FEBS Letters 72, 208-214

Mercier JC, Brignon G, Ribadeau-Dumas B (1973) Structure primaire de la caseine $k$-bovine. Sequence complète. Eur J Biochem 35, 222-235

Reiter B (1978) Review of the progress of dairy science: antimicrobial systems in milk. J Dairy Res 45, 131-147

Robitaille G, NG-Kwai-Hang KF, Monarde HG (1991) Variation in the $\mathrm{N}$-acetyl neuraminic acid content of bovine K-casein. J Dairy Res 58, 107-114

Saito $T$, Itoh $T$ (1992) Variations and distributions of o-glycosidically linked sugar chains in bovine $\kappa$-casein. J Dairy Sci 75, 1768-1774

Savalle B, Miranda G, Pélissier JP (1989) In vitro simulation of gastric digestion of milk proteins. J Agric Food Chem 37, 1336-1340

Shlygin GK, Vasilevskaya LS, Chernikov MP, Nikol'skaya GV (1971) "Anti-gastrin" action of glycomacropeptide. Bull Exp Biol Med 12, 9-13

Stan EY, Ekimovsky AP (1987) Peptide bioregulator from $x$-casein. Vopr Med Khim 33, 111-115 
Stan EY, Nikol'skaya GV, Chernikov MP (1974) Hydrolysis of glycomacropeptide from $\kappa$-casein with digestive proteinases. Vopr Pitan 3, 44-47

Stan EY, Aleinik SI, Chernikov MP (1983) The physiologically active $\kappa$-casein peptides. Fiziol $Z$ h SSSR $69,855-859$

Stan EY, Ekimovsky AP, Aleinik SI, Vasilevskaya LS, Chernikov MP (1986) Isolation, amino-acid composition and efficiency of the inhibitors of gastric secretion derived from $\kappa$-casein. Vopr Med Khim 32, 98-102

Vasilevskaya LS, Klimashima TA (1979) The action of parenterally introduced proteinic hydrolysates on the motor function of the stomach and duodenum. Vopr Pitan 5, 16-20

Vasilevskaya LS, Stan EY, Chernikov MP, Shlygin GK (1977) Inhibitory action of glycomacropeptide on the gastric secretion produced by various humoral stimulants. Vopr Pitan 4, 21-24
Vreeman HJ, Visser S, Slangen CJ, Van Riel JAM (1986) Characterization of bovine $\kappa$-casein fractions and the kinetics of chymosin-induced macropeptide release from carbohydrate-free and carbohydratecontaining fractions determined by high-performance gel-permeation chromatography. Biochem J 240, 87-97

Yvon M, Pélissier JP (1987) Characterization and kinetics of evacuation of peptides resulting from casein hydrolysis in the stomach of the calf. J Agric Food Chem 35, 148-156

Yvon M, Levieux D, Valluy MC, Pélissier JP, PatureauMirand $P$ (1993) Colostrum protein digestion in newborn lambs. J Nutr 123, 586-596

Zevaco C, Ribadeau-Dumas B (1984) A study on the carbohydrate binding sites of bovine $\kappa$-casein using high-performance liquid chromatography. Milchwissenschaft $39,206-210$ 